\title{
Synonymic Traps in Selected English Lexical Semantics Terms
}

\author{
K. Bednárová-Gibová \\ Institute of British and American Studies, University of Prešov \\ 1, ul. 17 Novembra, Prešov, Slovak Republic, 08001 \\ klaudia.gibova@unipo.sk
}

The paper zooms in on terminological and conceptual scrutiny of selected eight English lexical semantics terms with the aim of pointing out their terminological synonymy, which is often misrecognized by English linguistics undergraduates. Does a 'loose synonym' denote in lexical semantics the same thing as a 'partial synonym' or 'cognitive synonym'? Is the cognitive content of the term 'false friend' identical with that of a 'pseudosynonym' or 'paronym'? What aspects of the semantic continuum are shared and non-shared by the selected terms? These questions are at the core of this contribution which can serve didactic purposes of English linguistics teaching. The desk research findings are part of semantic and lexicographic studies and aspire to forewarn English linguistics undergraduates of conceptual misinterpretations in common lexical semantics terms. The paper operates from the perspective of cultural linguistics across the Anglophone semantic continuum. It is based on a tailored Sharifian's premise [2015] that the metalanguage of English lexical semantics is a repository of cultural conceptualizations that leave traces in its current terminological practice. The study suggests that some English lexical semantics terms offer a considerable space for their synonymic treatment, however, to the detriment of their correct conceptual decoding. The credit of the paper lies in raising undergraduates' awareness of metalinguistic terminology but also in increasing their conceptual fluency in the selected terms.

Key words: lexical semantics, terms, synonymy, conceptual fluency, cultural linguistics, linguistics undergraduates

\section{Article history:}

Received: 01.06.2019

Accepted: 15.09.2019

\section{For citation:}

Bednárová-Gibová, K. (2019). Synonymic traps in selected English lexical emantics terms. RUDN Journal of Language Studies, Semiotics and Semantics, 10(4), 754-760. doi: 10.22363/2313-22992019-10-4-754-760

\section{Bednárová-Gibová K., 2019.}

(c) (i) This work is licensed under a Creative Commons Attribution 4.0 International License https://creativecommons.org/licenses/by/4.0/ 


\title{
Синонимы-ловушки отдельных терминов лексической семантики английского языка
}

\author{
К. Беднарова-Гибова \\ Институт британских и американских исследований, Университет Прешова \\ 1, ул. 17 ноября, Прешов, Словачкая Республика, 08001 \\ klaudia.gibova@unipo.sk
}

\begin{abstract}
В статье рассматривается терминологическое и концептуальное изучение отдельных восьми терминов английской лексической семантики с целью выявления их терминологической синонимии, которая часто неправильно распознается студентами-лингвистами, изучающими английский язык. Означает ли «свободный синоним» в лексической семантике то же самое, что и «частичный синоним» или «когнитивный синоним»? Является ли когнитивное содержание термина «ложный друг» идентичным содержанию термина «псевдосиноним» или «пароним»? Какие аспекты семантического континуума обозначаются выбранными терминами? Эти вопросы лежат в основе этого исследования, который может служить дидактическим целям преподавания английской лингвистики. Результаты данной работы являются частью семантических и лексикографических исследований и направлены на то, чтобы предвосхитить концептуально неверные интерпретациии терминов общей лексической семантики. В статье используется лингвокультурный подход к англоязычному семантическому континууму. Он основан на идее Ф. Шарифиана о том, что метаязык английской лексической семантики является хранилищем культурных концептуализаций, которые оставляют следы в актуальной терминологической практике. Исследование предполагает, что некоторые английские термины лексической семантики предлагают значительное пространство для их синонимического объединения, однако в ущерб их правильному концептуальному декодированию. Целью данной работы является разделение данных терминов, уточнение данных вопросов металингвистической терминологии, а также повышение концептуальной беглости в использовании данных терминов.
\end{abstract}

Ключевые слова: лексическая семантика, термины, синонимия, концептуальная беглость, лингвокультура, студенты-лингвисты

\section{История статьи:}

Дата поступления: 01.06.2019

Дата приема в печать: 15.09.2019

\section{Для цитирования:}

Беднарова-Гибова $К$. Синонимы-ловушки отдельных терминов лексической семантики английского языка // Вестник Российского университета дружбы народов. Серия: Теория языка. Семиотика. Семантика. 2019. Т. 10. no 4. С. 754 -760. doi: 10.22363/2313-2299-2019-10-4-754-760

\section{Introduction}

Lexical semantics represents a fairly established branch of linguistics which is concerned with the study of lexis, its properties, use and meaning of words, and relations among lexical units of a language. Although there is a considerable variability of extant approaches in defining the scope of lexical semantics both in the Anglophone as well as continental linguistic zone [2], the terminological and conceptual mastery of its core terms is part and parcel of the metalanguage of linguistics. Under terminological mastery 
I understand being familiar with multiple terminological designations for the same linguistic concept whereas conceptual mastery involves a semantic decoding, interpretation and (hermeneutic) understanding of a term.

A true command of linguistics metalanguage within a selected sub-discipline, i.e. in our case lexical semantics, greatly contributes to the ease of the processing meaning of a term that is known as conceptual fluency [3]. The motivation for writing this paper stems from an authentic author's experience when teaching lexical semantics to second year English major students enrolled at the University of Prešov in Slovakia when a postcourse research experiment revealed that almost $70 \%$ of the focus group had difficulty identifying synonymic terminological designations for the identical lexical semantics concepts. This result testifies to the importance of raising awareness of the metalinguistic terminology, especially its synonymic variation in lexical semantics, on the part of university undergraduates.

This paper aims to point out terminological synonymy present in selected eight lexical semantic terms, which is, based on the conducted post-course research experiment, widely misrecognized by English linguistics undergraduates. The erroneous linguistic behaviour in terms of misidentifying synonymic 'traps' in the selected lexical semantics terms has been a driving force behind the proposed analytical probe. Borrowing from cultural linguistics and shedding light on the Anglophone semantic continuum, the paper is grounded in an adjusted Sharifian's premise [1] that the metalanguage of English lexical semantics represents a repository of cultural conceptualizations that leave traces in its current terminological practice. The paper is based on a hypothesis that lexical semantics terms exhibit a relatively high degree of synonymy, which complicates its linguistics metalanguage. In terms of methodology, the paper offers a terminological and conceptual analysis of the selected terms within the frame of lexical semantics; induction is employed in order to infer general conclusions from the individual cases. The assembled 'term-bank' and its analysis remains on an intralingual level only, i.e. within the Anglophone linguistic entrenchment. That said, this paper refrains from an intersemiotic treatment of the selected terms, which could be achieved by comparing their terminological and semantic scopes in two linguocultures, e.g. Anglophone and Slavic. Only multiple terminological designations consisting of three 'variations' minimum have been included, thus excluding synonymic variation restricted to 'double forms' like e.g. 'semantic field/lexical field' or 'antonym in narrow sense/antonym proper'.

\section{Theoretical points of departure behind the conceptualization of lexical semantics terms}

In contrast to ordinary lexical units as occurring in the vocabulary of general language, terms are used in specialized language. According to Cabré [4. P. 80], terms are "distinctive and meaningful signs which occur in special language discourse." She also views them as conventional symbols which stand for concepts defined within a particular field of knowledge [4. P. 81], i.e. in our case lexical semantics. Since terms result from a specialized area, their semantics can be considered deeper. If we accept Dolník's construal [5] that terms capture nodal points of scientific thinking then they make it possible for us to grasp the linguistics metalanguage cognitively. 
When outlining the relationship between a term and concept, as a rule, terms stand for concepts, or to put it more precisely, terms convey concepts. Kecskes and Papp [6. P. 42] contend that "the full acquisition and proper use of a concept requires the learner to know not only its [...] associative declarative knowledge but also the multimodal mental representation and culturally based behavioural scripts and schemas". Langacker [7. P. 28], building upon tenets of cognitive and cultural linguistics, proposes that "meaning is identified as conceptualization [and] cognition at all levels is both embodied and culturally embedded". This means that conceptual structures supposedly have a cultural basis, which brings us closer to the culturally constructed essence of conceptualization. Drawing on Dolník's understanding of conceptualization [8] and its subsequent reframing to lexical semantics, conceptualization refers to the competence of assigning meanings to the parts of the linguistics metalanguage, which is enabled by an individual's ability to recognize a pertinent interpretation of a particular term. Such linguistic behaviour on the part of the interpreter should result, however, in an adequate term's mental picture.

Lexical semantics terms in the Anglophone linguistic zone acquire meaning which is subject to cultural image-schemas that I understand in compliance with cognitive psychology as culturally constructed schemas that represent "building blocks of cognition used for storing, organizing, and interpreting [semantic] information" [1. P. 475]. An illustration of this cognitive approach would be reflected e.g. in the conceptual preference of the term 'lexical semantics' in Anglophone linguistics over the roughly synonymous 'lexicology' in the continental linguistic zone to denote a discipline which is concerned with a study of lexis and its meaning.

Although synonymy represents one of the basic sense relations among lexemes implying sameness of the denotative (i.e. conceptual/cognitive) meaning, its occurrence in linguistics metalanguage, and with lexical semantics in particular, can significantly impair conceptual fluency in English linguistics undergraduates. Therefore, I dare claim that the terminology of lexical semantics brims with a great many synonymic traps that the focus group under discussion should be made heedful of, at least by virtue of this paper. Below follows a brief terminological and conceptual analysis of the selected terms with a view to substantiating the paper's aim.

\section{Selected English Lexical Semantics Terms in Close-up}

The first term which merits attention is 'absolute synonym'; a type of a synonym that has the same meaning as another word agreeing in its denotative and connotative meaning and contextual distribution [2]. In the Anglophone culture-based linguistic schema also 'strict synonym' and 'total synonym' share the same aspects of the given semantic continuum although they are "extremely rare or even impossible" [10. P. 104]. However, a potentially synonymic trap must be excluded when considering 'stylistic' or 'ideographic' synonyms, which show the same denotation but a different connotation or a different degree of intensity or shade of meaning, respectively.

The second term is 'connotation' which is within the Anglophone cultural imageschema in a broader context easily interchangeable with that of 'connotative meaning', i.e. "supplementary subjective meaning of a word based on one's associations which 
include attitudinal or emotional factors" [9. P. 31]. The schema of speaker's individual mental understanding of an expression links it also with 'associative meaning'.

Similarly to the previous term, 'denotation' is synonymically related to 'denotational meaning/denotative meaning' in the sense of the primary dictionary meaning of a word conveying its basic conceptual properties. However, there is one more feature of the semantic continuum of the given term which is additional in the Anglophone cultural conceptualization, i.e. the act of denoting, the relationship between a linguistic form (signifiant) and the extra-linguistic thing (referent) it refers to, as present in a classic semiotic triangle. What baffles English linguistics undergraduates even more are synonymic traps like 'cognitive' or 'conceptual' meaning. In sum, the presence of five-fold synonymic variation in regard to the analysed term evidences a rich terminological variation in lexical semantics.

The fourth term is 'paronym' as a subtype of homonym where one word has a similar but not identical sound or spelling, but is in fact semantically completely different and only mistakenly interchangeable, e.g. collision - collusion, lose - loose. Other alternative terms such as 'false synonym' or 'pseudosynonym' further complicate the semantics meta-language. What is more, interlingual paronymy occurring between different languages gives rise to 'false friend' or 'faux ami' in compliance with a French linguo-cultural tradition. In this case, however, paronymy results not only from a fallacious semantic interlingual interpretation, but also from mistranslation. Owing to their intralingual dimension, 'paronym/false synonym/pseudosynonym' should not be muddled up with 'false friend/faux ami' which originate interlingually.

The fifth term that deserves a mention is 'loose synonym' whose encoded lexical meaning refers to "a word which has the same (cognitive) meaning as another word but is interchangeable only in some contexts and differs in its level of formality and connotations" [9. P. 72]. With regard to the collective salience of the given term in the sense of prominent meaning within the frame of lexical semantics, also 'partial synonym' or 'cognitive synonym' run rampant in the Anglophone conceptualizations under the influence of a cultural image-schema.

The penultimate term is that of 'semantic component' as the basic conceptual component of meaning that can be identified in componential analysis. The desk research into secondary sources has revealed that in Anglophone linguoculture also 'semantic feature' and 'seme' can be "personalized/privatized/subjectived" [11. P. 192] in the minds of linguistics users, all sharing the same segments of the semantic continuum. The existence of manifold terminological designations, as evidenced further by the said term, has a negative bearing on conceptual fluency in linguistics undergraduates, because they tend to be familiar with one term only.

The last term featured in this analysis is the abstract 'concept'. What complicates its correct decoding is the fact that in accordance with the culturally constructed nature of Anglophone conceptualization the term is endowed with two semantic readings. First, it is "an abstract idea, thought or mental construct which represents the basic characteristics of some objects in one's mind" and second, it refers to the "content aspect of the linguistic sign" [2. P. 99]. Some English clarifications of the term, however, 
do not encompass this semiotic angle. Other synonymic terms include the more philosophical 'idea' or 'thought' or the more professional 'reference' (not referent) and the Saussurian term 'signifié'. A weak degree of collective salience of the given term in the testees serves to confirm yet again that the hypothesis in this paper has been confirmed.

\section{Conclusion and implications}

To sum up, the paper has shown that cultural content of lexical semantics terms runs much deeper than one might think at first sight. It dispels a conventional stance that cultural content in the lexicon is unimportant for linguistics and terminology, in particular [see 12]. Both linguists as well as undergraduates should be made more perceptive to the legacy of terms as carriers of cultural meaning. Overall, lexical semantics terms exhibit a relatively high degree of synonymic variation, which can cause proverbial traps for linguistics undergraduates. These may lead to an inadequate mental picture of a given term because of the existence of other designations that the linguistics user may fail do decode semantically. Based on this paper, it is advisable that linguistics undergraduates consult special linguistics dictionaries and multiple terminological designations are made a natural part of their educational journey across linguistics terminology. In future research it would be relevant to explore if a comparable synonymic variation among terms exists in the second linguoculture and in a positive case scenario, to compare its semantic scope.

\section{References}

1. Sharifian, F. (2015). The Routledge Handbook of Language and Culture. London and New York: Routledge.

2. Bednárová-Gibová, K. (2018). Selected Chapters in English Lexicology. Part I: Lexical Semantics and Lexicography. Prešov: Vydavatel'stvo Prešovskej univerzity.

3. Lee, M.P., Yoon, C. \& Mitchell, A.A. (2004). Perceptual and Conceptual Fluency as Antecedents of the Mere Exposure Effect In: Research paper series. URL: https://pdfs.semanticscholar.org/ 9439/fd384d49f2dcc87544a14e80f8641c366670.pdf (accessed: 02.01.2019).

4. Cabré, M.T. (1999). Terminology: Theory, methods and applications. Amsterdam and Philadelphia: John Benjamins.

5. Dolnik, J. (2007). Lexicology. Bratislava: SPN. (In Slovak).

6. Kecskes, I. \& Papp, T. (2000). Foreign Language and a Mother Tongue. Mahwah, New Jersey: Lawrence Erlbaum Associates Publishers.

7. Langacker, R.W. (2014). Culture and cognition, lexicon and grammar In: M. Yamaguchi, D. Tay, B. Blount (eds.) Towards an Integration of Language, Culture and Cognition: Language in Cognitive, Historical, and Sociocultural Contexts. London: Palgrave Macmillan. pp. 27-49.

8. Dolník, J. (2009). General linguistics. Description and explanation of the language. Bratislava: Veda. (In Slovak).

9. Bilá, M., Kačmárová, A., Vaňková, I., Gumanová, G., Bednárová-Gibová, K. \& Eddy, E. (2018). A Handbook of English and Slovak Linguistic Terminology. Prešov: Prešovská univerzita v Prešove. URL: http://www.pulib.sk/web/kniznica/elpub/dokument/Bila6 (accessed: 03.12.2018).

10. Fuster-Márquez, M. (2012). An Introduction to English Lexicology: the Study of Form and Meaning. Valéncia: Universitat de Valéncia.

11. Keckes, I. (2014). Intercultural Pragmatics. Oxford: Oxford University Press.

12. Goddard, C. (2015). Words as Carriers of Cultural Meaning In: J.R. Taylor. The Oxford Handbook of the Word. Oxford: Oxford University Press. pp. 380-398. 


\section{Библиографический список}

1. Sharifian $F$. The Routledge Handbook of Language and Culture. London and New York: Routledge, 2015.

2. Bednárová-Gibová K. Selected Chapters in English Lexicology. Part I: Lexical Semantics and Lexicography. Prešov: Vydavatel'stvo Prešovskej univerzity, 2018.

3. Lee M.P., Yoon C., Mitchell A.A. Perceptual and Conceptual Fluency as Antecedents of the Mere Exposure Effect. In: Research paper series, 2004. Режим доступа: https://pdfs.semanticscholar.org/ 9439/fd384d49f2dcc87544a14e80f8641c366670.pdf (дата обращения: 02.01.2019).

4. Cabré M.T. Terminology: Theory, methods and applications. Amsterdam and Philadelphia: John Benjamins, 1999.

5. Dolnik J. Lexikológia. Bratislava: SPN, 2007.

6. Kecskes I., Papp T. Foreign Language and a Mother Tongue. Mahwah, New Jersey: Lawrence Erlbaum Associates Publishers, 2000.

7. Langacker R.W. Culture and cognition, lexicon and grammar// M. Yamaguchi, D. Tay, B. Blount (eds.) Towards an Integration of Language, Culture and Cognition: Language in Cognitive, Historical, and Sociocultural Contexts. London: Palgrave Macmillan, 2014. P. $27-49$.

8. Dolnik J. Všeobecná jazykoveda. Opis a vysvetl'ovanie jazyka. Bratislava: Veda, 2009.

9. Bilá M., Kačmárová A., Vaňková I., Gumanová G., Bednárová-Gibová K., Eddy E. A Handbook of English and Slovak Linguistic Terminology. Prešov: Prešovská univerzita v Prešove, 2018. Режим доступа: http://www.pulib.sk/web/kniznica/elpub/dokument/Bila6 (дата обращения: 03.12.2018).

10. Fuster-Márquez M. An Introduction to English Lexicology: the Study of Form and Meaning. Valéncia: Universitat de Valéncia, 2012.

11. Keckes I. Intercultural Pragmatics. Oxford: Oxford University Press, 2014.

12. Goddard C. Words as Carriers of Cultural Meaning // J.R. Taylor. The Oxford Handbook of the Word. Oxford: Oxford University Press, 2015. 380-398.

\section{Сведения об авторе:}

Беднарова-Гибова К., доктор филологических наук, доцент Института британских и американских исследований, факультет гуманитарных наук Прешовского университет (Словакия). Сфера научных интересов: английская лексикология, история английского языка, лингвистический анализ текста, анализ и перевод текстов юридического дискурса, теория и практика переводоведения; e-mail: klaudia.gibova@unipo.sk

\section{Information about the author:}

Klaudia Bednárová-Gibová, $\mathrm{PhD}$, Associate Professor of Translation Studies, Institute of British and American Studies, Faculty of Arts, University of Prešov, Slovakia. Research interests: English lexicology, history of the English language, linguistic text analysis, analysis and translation of legal texts, translation theory and practice; e-mail: klaudia.gibova@unipo.sk 